\title{
Preparation Conditions of $\mathrm{CaTiO}_{3}$ Film by Metal-Organic Chemical Vapor Deposition
}

\author{
Mitsutaka Sato ${ }^{1}$, Rong $\mathrm{Tu}^{2}$ and Takashi Goto ${ }^{2}$ \\ ${ }^{1}$ Department of Materials Science, Graduate School, Tohoku University, Sendai 980-8577, Japan \\ ${ }^{2}$ Institute for Materials Research, Tohoku University, Sendai 980-8577, Japan
}

Calcium titanate $\left(\mathrm{CaTiO}_{3}\right)$ films were prepared by metal-organic chemical vapor deposition (MOCVD) using $\mathrm{Ca}(\mathrm{dpm})_{2}$ and $\mathrm{Ti}(\mathrm{O}-\mathrm{i}-$ $\operatorname{Pr})_{2}(\mathrm{dpm})_{2}$ precursors. The phases, composition and morphology of Ca-Ti-O system films changed depending on molar ratio of $\mathrm{Ca}$ to $\mathrm{Ti}$ $\left(R_{\mathrm{Ca} / \mathrm{Ti}}\right)$, total pressure $\left(P_{\mathrm{tot}}\right)$ and substrate temperature $\left(T_{\mathrm{sub}}\right) . \mathrm{CaTiO}_{3}$ films in a single phase were obtained at the condition of $R_{\mathrm{Ca} / \mathrm{Ti}}=0.95$, $T_{\text {sub }}=1073 \mathrm{~K}$ and $P_{\text {tot }}=0.8 \mathrm{kPa}$, and $R_{\mathrm{Ca} / \mathrm{Ti}}=0.78, T_{\text {sub }}=973 \mathrm{~K}$ and $P_{\text {tot }}=0.8 \mathrm{kPa}$. The $\mathrm{CaTiO}_{3}$ films prepared at $T_{\text {sub }}=1073 \mathrm{~K}$ had a welldeveloped columnar texture, and significant (010) orientation was observed at $R_{\mathrm{Ca} / \mathrm{Ti}}$ from 0.59 to 0.72 . The deposition rate showed the highest value of $1.25 \times 10^{-8} \mathrm{~m} \mathrm{~s}^{-1}$ at $T_{\text {sub }}=1073 \mathrm{~K}, P_{\text {tot }}=0.4 \mathrm{kPa}$ and $R_{\mathrm{Ca} / \mathrm{Ti}}=0.95$. [doi:10.2320/matertrans.47.1386]

(Received December 22, 2005; Accepted March 31, 2006; Published May 15, 2006)

Keywords: metal-organic chemical vapor deposition, $\mathrm{CaTiO}_{3}$, crystal structure, microstructure, deposition rate

\section{Introduction}

Titanium (Ti) and its alloys have been applied as dental implants and artificial aggregate due to their good biocompatibility and mechanical properties. ${ }^{1,2)}$ It is known that the reproduction of bones on Ti substrates can be promoted by ceramic coatings including hydroxyapatite (HAp, $\left.\mathrm{Ca}_{10}\left(\mathrm{PO}_{4}\right)_{6}(\mathrm{OH})_{2}\right)$, calcium phosphate $\left(\mathrm{Ca}_{3}\left(\mathrm{PO}_{4}\right)_{2}\right)$ and calcium titanate $\left(\mathrm{CaTiO}_{3}\right)$. Then, many kinds of process have attempted to obtain these coatings by ion beam sputtering, ${ }^{3)}$ laser beam sputtering, ${ }^{4)}$ magnetic field sputtering, ${ }^{5)}$ sol-gel, $\left.{ }^{6}\right)$ aerosol-gel, ${ }^{7)}$ electrophoretic deposition, ${ }^{8)}$ plasma spray deposition ${ }^{9)}$ and ion beam evaporation. ${ }^{10)}$ In those processes, the adherence of coatings to the substrate is the primal issue for practical applications, and therefore several techniques have been developed by modifying the surface such as controlling surface roughness, ${ }^{11)}$ pre-oxidation of $\mathrm{Ti}$ surface forming $\mathrm{TiO}_{2},{ }^{12)} \mathrm{CaTiO}_{3}$ coating by sputtering as a buffer layer. ${ }^{13)}$ Although sputtering can provide well-adhered $\mathrm{CaTiO}_{3}$ coatings, the deposition rate could be too small, usually ranging from $10^{-11}$ to $10^{-12}$ $\mathrm{m} \mathrm{s}^{-1}$.

Chemical vapor deposition (CVD) is advantageous to obtain wide-ranged coatings at relatively high deposition rate with good morphology controllability and well-adherence to substrates, as indicated in the preparation of $\mathrm{TiO}_{2}{ }^{14)}$ and $\mathrm{ZrO}_{2}{ }^{15)}$ films. Although so many oxide and non-oxide films have been prepared by CVD, no report on the preparation of $\mathrm{CaTiO}_{3}$ films by CVD has been published.

In this study, $\mathrm{CaTiO}_{3}$ films were prepared by CVD using organometallic precursors and the effects of deposition conditions on phases, morphology, preferred orientation and deposition rate were investigated.

\section{Experimental Procedures}

A vertical cold-wall type CVD apparatus was employed to prepare Ca-Ti-O films. Source precursors of $\mathrm{Ca}(\mathrm{dpm})_{2}$ (bisdipivaloylmethanato-calcium) and $\mathrm{Ti}(\mathrm{O}-\mathrm{i}-\mathrm{Pr})_{2}(\mathrm{dpm})_{2}$ (bisisopropoxy-bis-dipivaloylmethanato-titanium) powders were heated at 523 to 573 and 393 to $453 \mathrm{~K}$, respectively. The source vapors were carried into the CVD reactor with Ar gas. $\mathrm{O}_{2}$ gas was separately introduced by using a double tube nozzle, and mixed with the precursor vapors in a mixing chamber placed above a substrate holder. The total gas flow rate $\left(F R_{\mathrm{tot}}=F R_{\mathrm{Ar}}+F R_{\mathrm{O}_{2}}+F R_{\text {source vapor }}\right)$ was fixed at $3.33 \times 10^{-6} \mathrm{~m}^{3} \mathrm{~s}^{-1}$. The total pressure $\left(P_{\text {tot }}\right)$ in the CVD reactor was kept in the range of 0.4 and $1.0 \mathrm{kPa}$. The deposition conditions are summarized in Table 1. Fused quartz glass plates of $10 \times 15 \times 0.5 \mathrm{~mm}$ were used as substrates because of identification of generation phase and observation of broken-out section can be performed easily. The crystal structure was analyzed by X-ray diffraction (XRD). The microstructure and thickness of deposited films were examined by scanning electron microscopy (SEM). The deposition rate $\left(R_{\text {dep }}\right)$ was determined from the relationship between thickness and deposition time.

The thermodynamic calculation was conducted to estimate the stable solid phases and gas compositions, as functions of deposition conditions, that is often called as CVD phase diagram. The equilibrium compositions of gas and solid species in the Ca-Ti-C-H-O system at various deposition conditions were calculated by free energy minimization

Table 1 Deposition conditions of Ca-Ti-O films.

$\begin{array}{ll}\text { Precursor Temperature, } T_{\text {prec }} & \\ \mathrm{Ca}(\mathrm{dpm})_{2} & : 323-573 \mathrm{~K} \\ \mathrm{Ti}(\mathrm{O}-\mathrm{i}-\mathrm{Pr})_{2}(\mathrm{dpm})_{2} & : 193-453 \mathrm{~K} \\ \text { Total gas flow rate, } F R_{\text {tot }} & : 3.33 \times 10^{-6} \mathrm{~m}^{3} \mathrm{~s}^{-1} \\ \text { Carrier Gas } & : \mathrm{Ar} \\ \mathrm{Ca}(\mathrm{dpm})_{2} & : 0.83 \times 10^{-6} \mathrm{~m}^{3} \mathrm{~s}^{-1} \\ \mathrm{Ti}(\mathrm{O}-\mathrm{i}-\mathrm{Pr})_{2}(\mathrm{dpm})_{2} & : 0.83 \times 10^{-6} \mathrm{~m}^{3} \mathrm{~s}^{-1} \\ \text { Oxidation Gas } & : \mathrm{O}_{2} \\ \mathrm{O}_{2} \text { gas flow rate, } F R_{\mathrm{O}_{2}} & : 0.17-1.5 \times 10^{-6} \mathrm{~m}^{3} \mathrm{~s}^{-1} \\ \text { Total pressure, } P_{\text {tot }} & : 0.4-1.0 \mathrm{kPa} \\ \text { Deposition temperature, } T_{\text {sub }} & : 873-1123 \mathrm{~K} \\ \text { Deposition time } & : 0.9 \mathrm{ks} \\ \text { Substrate } & : \text { fused quartz glass }\end{array}$


Table 2 Chemical species used in the thermodynamic calculation.

\begin{tabular}{llll}
\hline Gas species & & & \\
$\mathrm{Ar}$ & $\mathrm{O}$ & $\mathrm{O}_{2}$ & $\mathrm{H}$ \\
$\mathrm{H}_{2}$ & $\mathrm{HO}$ & $\mathrm{CO}$ & $\mathrm{CO}_{2}$ \\
$\mathrm{H}_{2} \mathrm{O}$ & $\mathrm{HCO}$ & $\mathrm{H}_{2} \mathrm{O}_{2}$ & $\mathrm{HO}_{2}$ \\
$\mathrm{CH}_{4}$ & $\mathrm{CH}_{2} \mathrm{O}$ & $\mathrm{CH}_{2} \mathrm{O}_{2}$ & $\mathrm{CaO}$ \\
$\mathrm{TiO}$ & $\mathrm{TiO}_{2}$ & & \\
$\mathrm{Solid}$ species & & & \\
$\mathrm{TiO}(\alpha)$ & $\mathrm{TiO}(\beta)$ & $\mathrm{TiO}(\gamma)$ & $\mathrm{TiO}_{2}$ (anatase) \\
$\mathrm{TiO}_{2}($ rutile $)$ & $\mathrm{Ti}_{2} \mathrm{O}_{3}$ & $\mathrm{Ti}_{3} \mathrm{O}_{5}$ & $\mathrm{Ti}_{3} \mathrm{O}_{5}(\beta)$ \\
$\mathrm{Ti}_{4} \mathrm{O}_{7}(\gamma)$ & $\mathrm{TiC}$ & $\mathrm{CH}_{2} \mathrm{O}$ & $\mathrm{CaO}$ \\
$\mathrm{CaO}_{2}$ & $\mathrm{CaCO}_{3}$ & $\mathrm{CaTiO}_{3}$ & $\mathrm{Ca}_{3} \mathrm{Ti}_{2} \mathrm{O}_{7}$ \\
$\mathrm{Ca}_{4} \mathrm{Ti}_{3} \mathrm{O}_{10}$ & & & \\
\hline
\end{tabular}

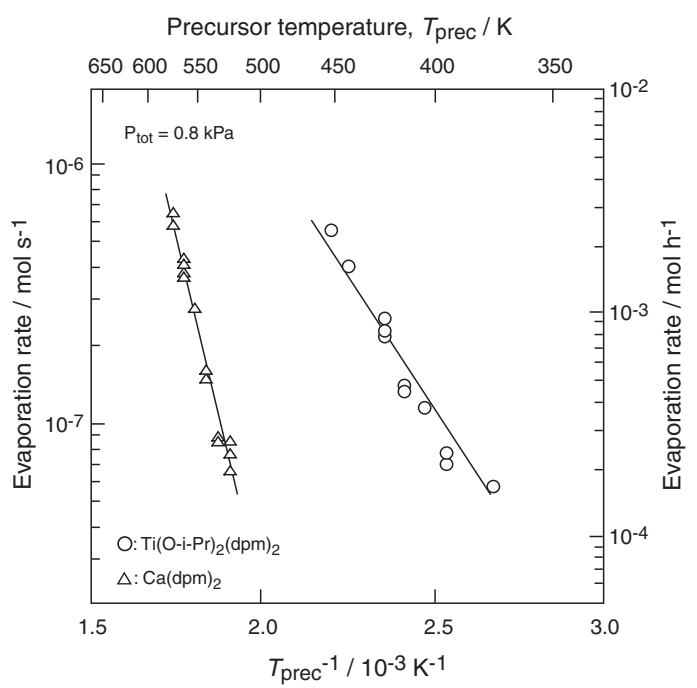

Fig. 1 Effect of precursor temperature on the evaporation rate of $\mathrm{Ca}(\mathrm{dpm})_{2}$ and $\mathrm{Ti}(\mathrm{O}-\mathrm{i}-\mathrm{Pr})_{2}(\mathrm{dpm})_{2}$ at $P_{\mathrm{O}_{2}}=0.32 \mathrm{kPa}$ and $P_{\text {tot }}=0.8 \mathrm{kPa}$.

method using SOLGASMIX-PV. ${ }^{16)}$ Chemical species considered in the calculation are summarized in Table 2. The thermodynamic data for chemical species were taken from Refs. 17) and 18).

\section{Results and Discussion}

\subsection{Crystal structure}

Figure 1 shows the relationship between precursor temperature $\left(T_{\text {prec }}\right)$ and the evaporation rate of $\mathrm{Ca}(\mathrm{dpm})_{2}$ and $\mathrm{Ti}(\mathrm{O}-\mathrm{i}-$ $\mathrm{Pr})_{2}(\mathrm{dpm})_{2}$. The evaporation rates exponentially increased with increasing temperature. Although the evaporation rate of $\mathrm{Ti}(\mathrm{O}-\mathrm{i}-\mathrm{Pr})_{2}(\mathrm{dpm})_{2}$ was 100 times greater than that of $\mathrm{Ca}(\mathrm{dpm})_{2}$, the precursor molar ratio of $\mathrm{Ca}$ to $\mathrm{Ti}\left(R_{\mathrm{Ca} / \mathrm{Ti}}\right)$ was precisely controlled by changing the evaporation temperature.

Figure 2 shows X-ray diffraction patterns of Ca-Ti-O films prepared at $P_{\text {tot }}=0.8 \mathrm{kPa}, P_{\mathrm{O}_{2}}=0.32 \mathrm{kPa}, T_{\text {sub }}=873$ to $1073 \mathrm{~K}$ and $R_{\mathrm{Ca} / \mathrm{Ti}} \simeq 1 . \mathrm{Ca}_{4} \mathrm{Ti}_{3} \mathrm{O}_{10}$ and $\mathrm{CaO}$ mixed films were obtained at $T_{\text {sub }}=873 \mathrm{~K}$, and $\mathrm{Ca}(\mathrm{OH})_{2}$ contained $\mathrm{CaTiO}_{3}$ films were obtained at $T_{\text {sub }}=973 \mathrm{~K}$. At $T_{\text {sub }}=$ $1073 \mathrm{~K}, \mathrm{CaTiO}_{3}$ films in a single phase were obtained. $\mathrm{CaTiO}_{3}$ and $\mathrm{Ca}_{4} \mathrm{Ti}_{3} \mathrm{O}_{10}$ are orthorhombic belonging to the

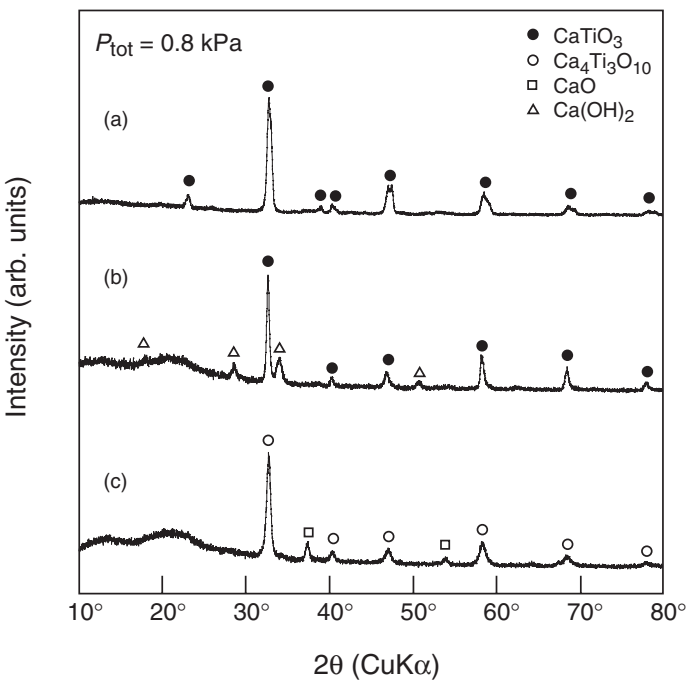

Fig. 2 XRD patterns of Ca-Ti-O films prepared at $P_{\mathrm{O}_{2}}=0.32 \mathrm{kPa}$ and $P_{\text {tot }}=0.8 \mathrm{kPa}$. (a) $T_{\text {sub }}=1073 \mathrm{~K}$ and $R_{\mathrm{Ca} / \mathrm{Ti}}=0.95$, (b) $T_{\text {sub }}=973 \mathrm{~K}$ and $R_{\mathrm{Ca} / \mathrm{Ti}}=1.02$, (c) $T_{\text {sub }}=873 \mathrm{~K}$ and $R_{\mathrm{Ca} / \mathrm{Ti}}=0.9$.

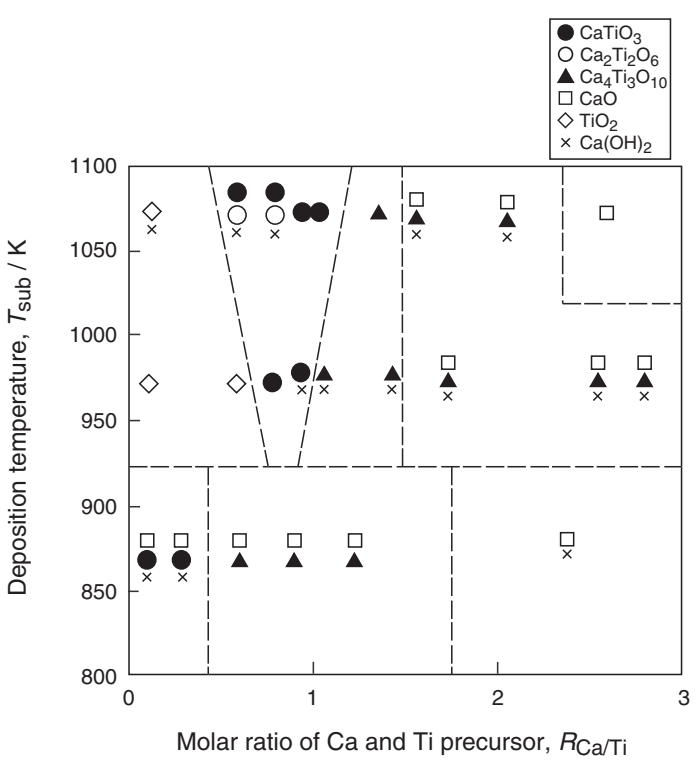

Fig. $3 T_{\text {sub }}-R_{\mathrm{Ca} / \mathrm{Ti}}$ phase diagram of Ca-Ti-O films at $P_{\mathrm{O}_{2}}=0.32 \mathrm{kPa}$ and $P_{\text {tot }}=0.8 \mathrm{kPa}$.

space group of Pnma and Pcab, respectively. The lattice parameters of $\mathrm{CaTiO}_{3}$ are $a=0.5442 \mathrm{~nm}, b=0.7641 \mathrm{~nm}$ and $c=0.5380 \mathrm{~nm}$, and those of $\mathrm{Ca}_{4} \mathrm{Ti}_{3} \mathrm{O}_{10}$ are $a=$ $0.5408 \mathrm{~nm}, b=2.714 \mathrm{~nm}$ and $c=0.5433 \mathrm{~nm}$ which were taken from JCPDS data. ${ }^{19,20)}$ The phases of $\mathrm{CaTiO}_{3}$ and $\mathrm{Ca}_{4} \mathrm{Ti}_{3} \mathrm{O}_{10}$ in the films depicted in Figs. 2(a) and (c) were quasi-tetragonal structure due to broadening of peaks, and these lattice parameters were calculated as $a=0.548 \mathrm{~nm}$, $b=0.764 \mathrm{~nm}$ for $\mathrm{CaTiO}_{3}$ phase and $a=0.546 \mathrm{~nm}, b=$ $2.73 \mathrm{~nm}$ for $\mathrm{Ca}_{4} \mathrm{Ti}_{3} \mathrm{O}_{10}$ phase.

Figure 3 summarizes the $T_{\text {sub }}-R_{\mathrm{Ca} / \mathrm{Ti}}$ phase diagram of Ca-Ti-O films at $P_{\text {tot }}=0.8 \mathrm{kPa}$ and $P_{\mathrm{O}_{2}}=0.32 \mathrm{kPa}$. At $T_{\text {sub }}=873 \mathrm{~K}$, mixture films of $\mathrm{CaTiO}_{3}, \mathrm{CaO}$ and $\mathrm{Ca}(\mathrm{OH})_{2}$ were obtained at $R_{\mathrm{Ca} / \mathrm{Ti}}<0.5$, and mixture films of $\mathrm{Ca}_{4} \mathrm{Ti}_{3} \mathrm{O}_{10}$ and $\mathrm{CaO}$ were obtained at $0.5<R_{\mathrm{Ca} / \mathrm{Ti}}<2$, and mixture films of $\mathrm{CaO}$ and $\mathrm{Ca}(\mathrm{OH})_{2}$ were obtained at 


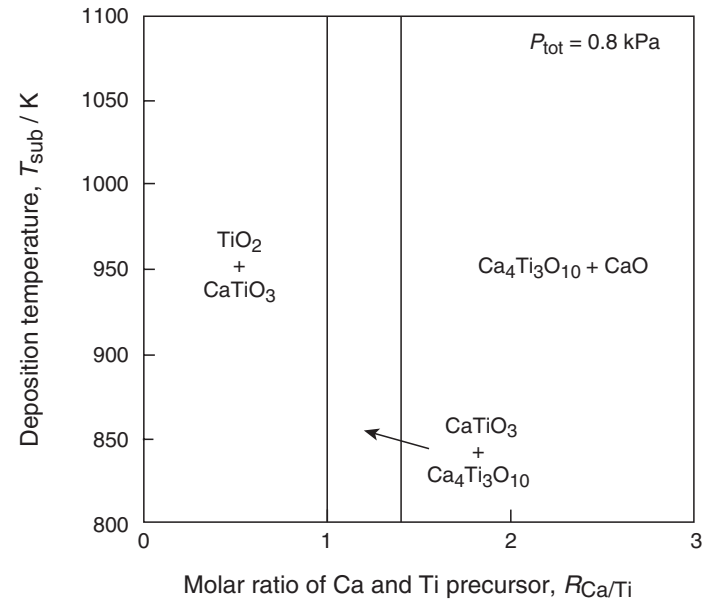

Fig. 4 Calculated CVD phase diagram for the $\mathrm{Ca}-\mathrm{Ti}-\mathrm{O}$ system at $P_{\text {tot }}=0.8 \mathrm{kPa}$ and $P_{\mathrm{O}_{2}}=0.32 \mathrm{kPa}$.

$R_{\mathrm{Ca} / \mathrm{Ti}}>2$. At $T_{\text {sub }}=973 \mathrm{~K}, \mathrm{TiO}_{2}$ films (anatase) were obtained at $R_{\mathrm{Ca} / \mathrm{Ti}}<0.8$, and $\mathrm{CaTiO}_{3}$ in a single phase or containing small amount of $\mathrm{Ca}(\mathrm{OH})_{2}$ were obtained at $0.8<R_{\mathrm{Ca} / \mathrm{Ti}}<1.02 . \mathrm{Ca}_{4} \mathrm{Ti}_{3} \mathrm{O}_{10}$ films with a small amount of $\mathrm{Ca}(\mathrm{OH})_{2}$ were obtained at $1.02<R_{\mathrm{Ca} / \mathrm{Ti}}<1.5$, and mixture films of $\mathrm{Ca}_{4} \mathrm{Ti}_{3} \mathrm{O}_{10}, \mathrm{CaO}$ and $\mathrm{Ca}(\mathrm{OH})_{2}$ were obtained at $R_{\mathrm{Ca} / \mathrm{Ti}}>1.5$. At $T_{\text {sub }}=1073 \mathrm{~K}, \mathrm{TiO}_{2}$ films (anatase) were obtained at $R_{\mathrm{Ca} / \mathrm{Ti}}<0.6$, and $\mathrm{CaTiO}_{3}$ films in a single phase or with a small amount of $\mathrm{Ca}_{2} \mathrm{Ti}_{2} \mathrm{O}_{6}$ were obtained at $0.6<R_{\mathrm{Ca} / \mathrm{Ti}}<1.2$. $\mathrm{Ca}(\mathrm{OH})_{2}$ were occasionally contained. $\mathrm{Ca}_{4} \mathrm{Ti}_{3} \mathrm{O}_{10}$ films with $\mathrm{Ca}(\mathrm{OH})_{2}$ were obtained at $1.2<$ $R_{\mathrm{Ca} / \mathrm{Ti}}<1.5$, and mixture films of $\mathrm{Ca}_{4} \mathrm{Ti}_{3} \mathrm{O}_{10}$ and $\mathrm{CaO}$ were obtained at $1.5<R_{\mathrm{Ca} / \mathrm{Ti}}<2.4$, and $\mathrm{CaO}$ films in a single phase were obtained at $R_{\mathrm{Ca} / \mathrm{Ti}}>2.4 . \mathrm{Ca}(\mathrm{OH})_{2}$ phase obtained in wide-ranged conditions may be formed by the reaction of $\mathrm{CaO}$ and moisture in air after the deposition.

Figure 4 shows the calculated CVD phase diagram of the Ca-Ti-O system at $P_{\text {tot }}=0.8 \mathrm{kPa}$ and $P_{\mathrm{O}_{2}}=0.32 \mathrm{kPa}$. By comparing Fig. 3 with Fig. 4 , the general trend changing from $\mathrm{TiO}_{2}, \mathrm{CaTiO}_{3}, \mathrm{Ca}_{4} \mathrm{Ti}_{3} \mathrm{O}_{10}$ to $\mathrm{CaO}$ with increasing $R_{\mathrm{Ca} / \mathrm{Ti}}$ was in agreement with the experiments. At $T_{\text {sub }}$ less than $900 \mathrm{~K}$, the $\mathrm{CaO}$ formation could be kinetically easier than the $\mathrm{TiO}_{2}$ formation. Consequently, $\mathrm{CaTiO}_{3}$ phase was obtained at low $\mathrm{Ca}$ concentration conditions. This may be caused by some kinetic reason. It can be understood that the thermodynamic equilibrium is almost attained at $T_{\text {sub }}>950 \mathrm{~K}$. Figure 5 demonstrates the calculated effect of oxygen partial pressure $\left(P_{\mathrm{O}_{2}}\right)$ on the formation of free-carbon. The calculation suggests that hydrocarbons contained in the metalorganic precursors could be co-deposited as free-carbon at $P_{\mathrm{O}_{2}}<3 \mathrm{~Pa}$. In the present experiments, the $P_{\mathrm{O}_{2}}$ was kept at 40 to $360 \mathrm{~Pa}$, and the sufficient amount of oxygen was supplied to eliminate free-carbon in the films.

\subsection{Microstructure}

Figure 6 shows the effect of $P_{\mathrm{O}_{2}}$ on the surface morphology of $\mathrm{CaTiO}_{3}$ films almost in a single phase prepared at $R_{\mathrm{Ca} / \mathrm{Ti}}=0.95, T_{\mathrm{sub}}=1073 \mathrm{~K}$ and $P_{\text {tot }}=0.8 \mathrm{kPa}$. The grain size increased with increasing $P_{\mathrm{O}_{2}}$, being about $50 \mathrm{~nm}$ and 2 to $3 \mu \mathrm{m}$ at $P_{\mathrm{O}_{2}}=0.08$ and $0.32 \mathrm{kPa}$, respectively.

Figure 7 depicts the effect of $T_{\text {sub }}$ on the surface and cross-

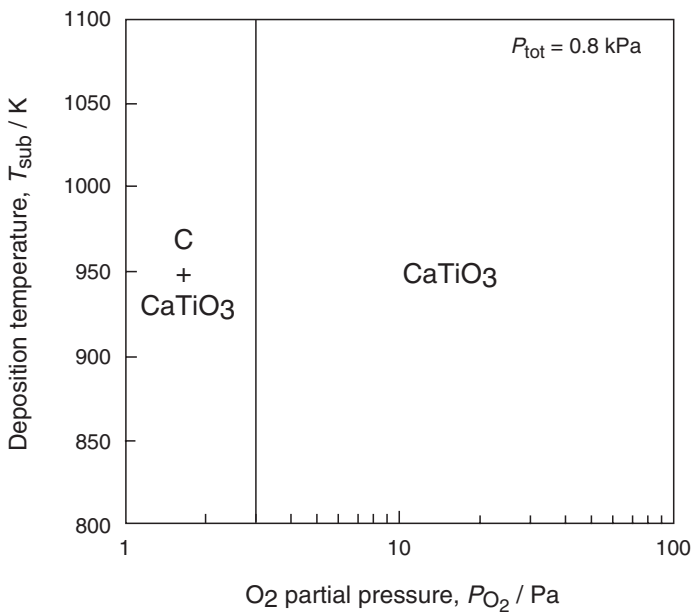

Fig. 5 Effect of oxygen partial pressure on the deposition of carbon at $P_{\text {tot }}=0.8 \mathrm{kPa}$ and $R_{\mathrm{Ca} / \mathrm{Ti}} \simeq 1$.
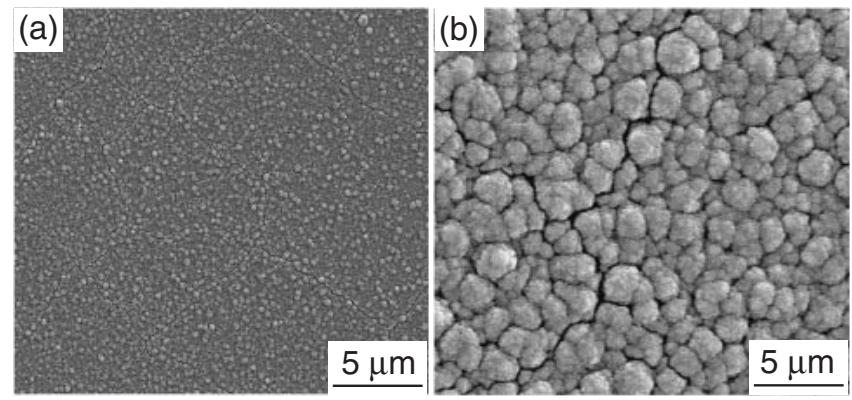

Fig. 6 Effect of $P_{\mathrm{O}_{2}}$ on the surface morphology of $\mathrm{CaTiO}_{3}$ films prepared at $R_{\mathrm{Ca} / \mathrm{Ti}}=0.95, T_{\text {sub }}=1073 \mathrm{~K}$ and $P_{\text {tot }}=0.8 \mathrm{kPa}$. (a) $P_{\mathrm{O}_{2}}=0.08 \mathrm{kPa}$, (b) $P_{\mathrm{O}_{2}}=0.32 \mathrm{kPa}$.
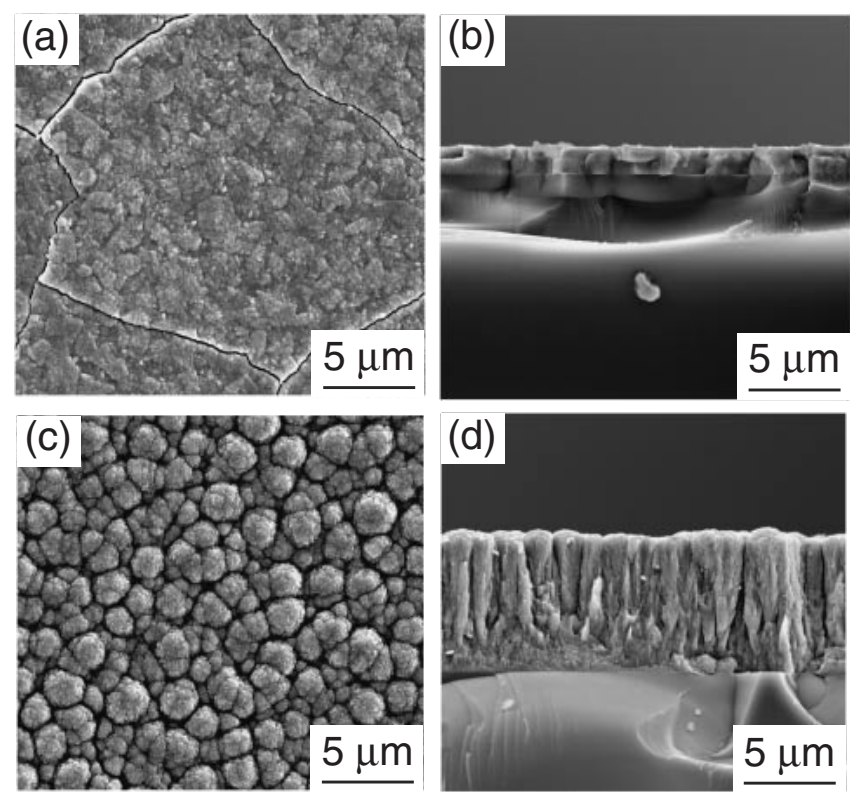

Fig. 7 Effect of $T_{\text {sub }}$ on the surface and cross-sectional morphology of $\mathrm{CaTiO}_{3}$ films prepared at $P_{\mathrm{O}_{2}}=0.32 \mathrm{kPa}$ and $P_{\text {tot }}=0.8 \mathrm{kPa}$. (a), (b): $T_{\text {sub }}=873 \mathrm{~K}(\mathrm{c}),(\mathrm{d}): T_{\text {sub }}=1073 \mathrm{~K}$.

sectional morphology of $\mathrm{CaTiO}_{3}$ films prepared at $R_{\mathrm{Ca} / \mathrm{Ti}}=0.95, P_{\text {tot }}=0.8 \mathrm{kPa}$ and $P_{\mathrm{O}_{2}}=0.32 \mathrm{kPa}$. The film prepared at $T_{\text {sub }}=873 \mathrm{~K}$ had dense microstructure, and the 

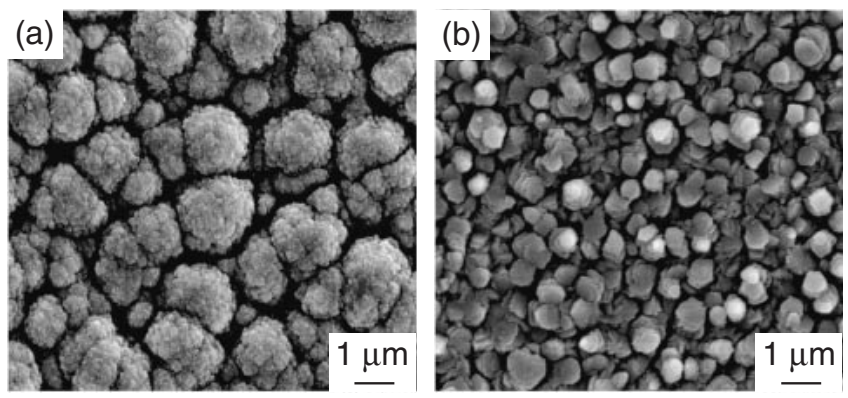

Fig. 8 Effect of $R_{\mathrm{Ca} / \mathrm{Ti}}$ on the surface morphology of $\mathrm{CaTiO}_{3}$ films prepared at $P_{\mathrm{O}_{2}}=0.32 \mathrm{kPa}, P_{\text {tot }}=0.8 \mathrm{kPa}$ and $T_{\text {sub }}=1073 \mathrm{~K}$. (a) $R_{\mathrm{Ca} / \mathrm{Ti}}=0.95$, (b) $R_{\mathrm{Ca} / \mathrm{Ti}}=0.72$.

grain size was about $50 \mathrm{~nm}$. Significant cracks were observed. This may be caused by the thermal expansion mismatch between $\mathrm{CaTiO}_{3}$ film and quartz substrate $\left(\alpha_{\mathrm{CaTiO}_{3}}=12.2 \times\right.$ $\left.10^{-6} \mathrm{~K}^{-1}, \alpha_{\text {quarts }}=0.5 \times 10^{-6} \mathrm{~K}^{-1}\right)$. The $\mathrm{CaTiO}_{3}$ film prepared at $T_{\text {sub }}=1073 \mathrm{~K}$ showed a cauliflower-like texture with the grain size of 2 to $3 \mu \mathrm{m}$. These grains consisted of farther smaller grains about $50 \mathrm{~nm}$ in diameter. The crosssectional view showed a well-developed columnar texture (Fig. 7(d)). The significant increase in grain size with increasing $P_{\mathrm{O}_{2}}$ and $T_{\text {sub }}$ could be associated with the change of microstructure from dense to columnar texture. It is generally understood that the texture changes from dense to columnar to dendrite to plate single crystal with increasing substrate temperature and decreasing supersaturation of precursors in the gas phase. ${ }^{21)}$ In the present study, the significant grain growth with $P_{\mathrm{O}_{2}}$ can be caused by the decrease of supersaturation of precursors due to the homogeneous reactions (powder formation) in the gas phase. The $\mathrm{CaTiO}_{3}$ film prepared at $T_{\text {sub }}=1073 \mathrm{~K}$ had almost no cracks. The columnar texture had small gaps between each elongated grains. It is well understood that these gaps can be effective to relax the thermal stress between films and the substrate resulting to less cracking as reported in YSZ (yttria stabilized zirconia) coatings on Ni-base super alloys. ${ }^{22}$ )

Figure 8 shows the effect of $R_{\mathrm{Ca} / \mathrm{Ti}}$ on the surface morphology of $\mathrm{CaTiO}_{3}$ films in a single phase (a) and containing a small amount of $\mathrm{Ca}_{2} \mathrm{Ti}_{2} \mathrm{O}_{6}$ (b) prepared at $P_{\text {tot }}=0.8 \mathrm{kPa}$ and $T_{\text {sub }}=1073 \mathrm{~K}$, respectively. Although the film prepared at $R_{\mathrm{Ca} / \mathrm{Ti}}=0.95$ had a cauliflower-like texture, the each grain showed angular edges. The edged shape developed with decreasing $R_{\mathrm{Ca} / \mathrm{Ti}}$, and almost hexagonal grains were observed at $R_{\mathrm{Ca} / \mathrm{Ti}}=0.72$.

Figure 9 shows the effect of $R_{\mathrm{Ca} / \mathrm{Ti}}$ on the XRD patterns of the films prepared at $P_{\text {tot }}=0.8 \mathrm{kPa}, T_{\text {sub }}=1073 \mathrm{~K}$ and $P_{\mathrm{O}_{2}}=0.32 \mathrm{kPa}$. Significant (010) orientation was appeared at $R_{\mathrm{Ca} / \mathrm{Ti}}=0.59$ and 0.72 , where a small amount of $\mathrm{Ca}_{2} \mathrm{Ti}_{2} \mathrm{O}_{6}$ was co-deposited. The (010) orientation and co-deposition of $\mathrm{Ca}_{2} \mathrm{Ti}_{2} \mathrm{O}_{6}$ were observed only at $T_{\text {sub }}=1073 \mathrm{~K}$. The $\mathrm{Ca}_{2} \mathrm{Ti}_{2} \mathrm{O}_{6}$ formation will be described in detail elsewhere.

\subsection{Deposition rate}

Figure 10 depicts the effect of $P_{\mathrm{O}_{2}}$ on the deposition rate $\left(R_{\mathrm{dep}}\right)$ at $R_{\mathrm{Ca} / \mathrm{Ti}} \simeq 1, T_{\text {sub }}=1023 \mathrm{~K}$ and $P_{\text {tot }}=0.8 \mathrm{kPa}$. The $R_{\text {dep }}$ increased with increasing $P_{\mathrm{O}_{2}}$. It can be understood that the $R_{\text {dep }}$ was controlled by oxygen supply (mass transfer

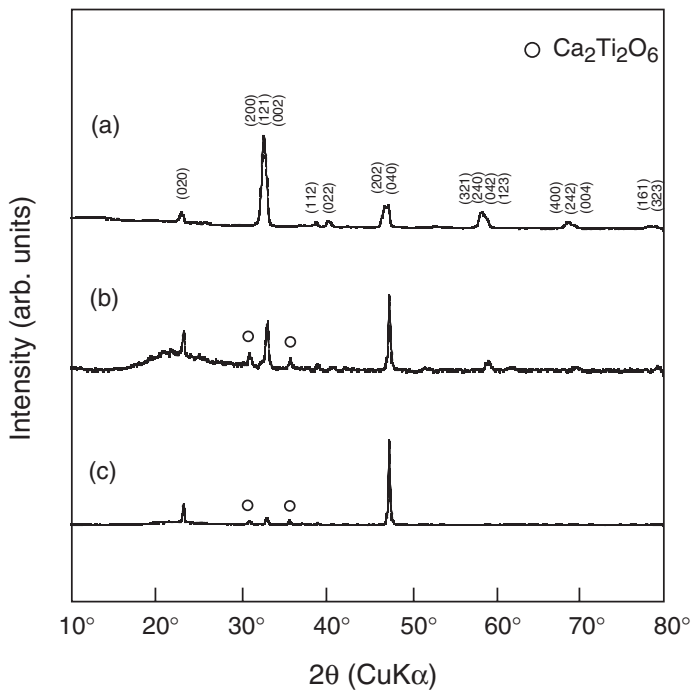

Fig. 9 XRD patterns of $\mathrm{CaTiO}_{3}$ films prepared at $P_{\mathrm{O}_{2}}=0.32 \mathrm{kPa}$, $P_{\text {tot }}=0.8 \mathrm{kPa}$ and $T_{\text {sub }}=1073 \mathrm{~K}$. (a) $R_{\mathrm{Ca} / \mathrm{Ti}}=0.95$, (b) $R_{\mathrm{Ca} / \mathrm{Ti}}=0.72$, (c) $R_{\mathrm{Ca} / \mathrm{Ti}}=0.59$.

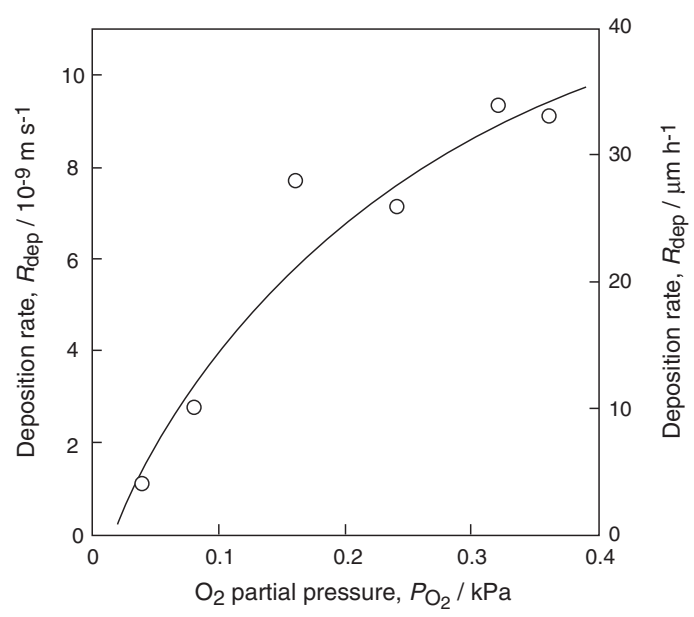

Fig. 10 Effect of $P_{\mathrm{O}_{2}}$ on the deposition rate at $T_{\text {sub }}=1023 \mathrm{~K}$ and $P_{\text {tot }}=0.8 \mathrm{kPa}$.

controlled process) which is consisted with the $T_{\text {sub }}$ dependence of $R_{\text {dep }}$ will be discussed later.

Figure 11 shows the effect of $P_{\text {tot }}$ on the $R_{\text {dep }}$ at $R_{\mathrm{Ca} / \mathrm{Ti}} \simeq 1$, $P_{\mathrm{O}_{2}}=0.36 \mathrm{kPa}$ and $T_{\text {sub }}=873 \mathrm{~K}$. The deposition rate had a maximum value at $P_{\text {tot }}=0.4 \mathrm{kPa}$. The similar phenomena were obtained at $T_{\text {sub }}=973$ and $1073 \mathrm{~K}$. In CVD, the deposition rate generally increases with source gas supply which is obviously increased with total pressure. However, the homogenous reaction in the gas phase could proceed more significantly at higher total pressures. Therefore, it is common that the deposition rate has a maximum at a specific total pressure. The similar $P_{\text {tot }}-R_{\text {dep }}$ relationship were observed in $T_{\text {sub }}=973$ and $1073 \mathrm{~K}$.

Figure 12 shows the relationship between $T_{\text {sub }}$ and $R_{\text {dep }}$ at $R_{\mathrm{Ca} / \mathrm{Ti}} \simeq 1, P_{\mathrm{O}_{2}}=0.32 \mathrm{kPa}$ in the Arrhenius format. The $R_{\mathrm{dep}}$ increased with increasing $T_{\text {sub }}$, and showed a maximum value of $1.11 \times 10^{-8}$ and $1.25 \times 10^{-8} \mathrm{~m} \mathrm{~s}^{-1}$ at $P_{\text {tot }}=0.8$ and $0.4 \mathrm{kPa}$, respectively. At $T_{\text {sub }}=1123 \mathrm{~K}$, the deposition rate slightly decreased, which may be caused by the homoge- 


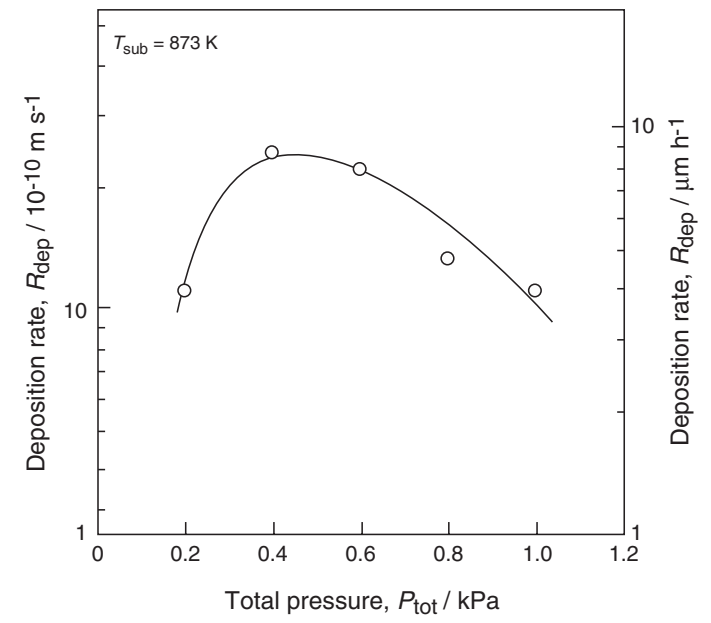

Fig. 11 Effect of $P_{\text {tot }}$ on the deposition rate at $P_{\mathrm{O}_{2}}=0.32 \mathrm{kPa}$ and $T_{\text {sub }}=873 \mathrm{~K}\left(T_{\text {prec }}(\mathrm{Ca})=533 \mathrm{~K}, T_{\text {prec }}(\mathrm{Ti})=313 \mathrm{~K}\right)$.

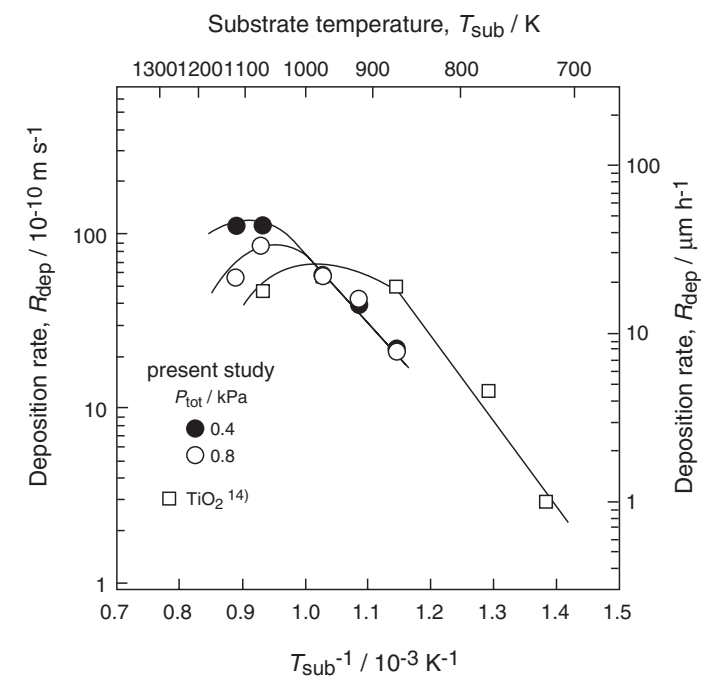

Fig. 12 Effect of $T_{\text {sub }}$ on the deposition rates at $P_{\mathrm{O}_{2}}=0.32 \mathrm{kPa}$.

neous reaction in the gas phase. ${ }^{21)}$ The higher total pressure, the more homogeneous reaction in the gas phase. Therefore, the $R_{\text {dep }}$ decreased more significantly over $T_{\text {sub }}=1123 \mathrm{~K}$ at higher $P_{\text {tot }}$. The activation energies for $P_{\text {tot }}=0.4$ and $0.8 \mathrm{kPa}$ in the low temperature region were both about $70 \mathrm{~kJ} \mathrm{~mol}^{-1}$. It is known that the rate-controlling step in CVD could be a diffusion-limited process in a high $T_{\text {sub }}$ region with an activation energy of a few $\mathrm{kJ} \mathrm{mol}^{-1}$ and chemical reaction limited process in a low $T_{\text {sub }}$ region with an activation energy of more than several $10 \mathrm{~kJ} \mathrm{~mol}^{-1}$. $^{21)}$ The activation energy of $70 \mathrm{~kJ} \mathrm{~mol}^{-1}$ in the present study could suggest chemical reaction limited process in the low $T_{\text {sub }}$ region. Further study should be necessary to understand the deposition mechanism $\mathrm{CaTiO}_{3}$ films by CVD. Since no paper for the preparation of $\mathrm{CaTiO}_{3}$ films by CVD method has been published, the results of $\mathrm{TiO}_{2}{ }^{14)}$ films by $\mathrm{CVD}$ using the same CVD apparatus with almost the same conditions were included in Fig. 12. The trend of the relationship between the $R_{\text {dep }}$ and the $T_{\text {sub }}$ for $\mathrm{TiO}_{2}$ films was the same as the present study. The deposition of $\mathrm{CaTiO}_{3}$ films may be closely associated with the formation of $\mathrm{TiO}_{2}$ films.

\section{Conclusions}

Ca-Ti-O films were prepared by CVD using $\mathrm{Ca}(\mathrm{dpm})_{2}$ and $\mathrm{Ti}(\mathrm{O}-\mathrm{i}-\mathrm{Pr})_{2}(\mathrm{dpm})_{2}$ precursors. $\mathrm{CaTiO}_{3}$ films in a single phase were obtained at $T_{\text {sub }}=973$ to $1073 \mathrm{~K}, R_{\mathrm{Ca} / \mathrm{Ti}}=0.78$ to 0.95 , $P_{\mathrm{O}_{2}}=0.32 \mathrm{kPa}$ and $P_{\text {tot }}=0.8 \mathrm{kPa}$. The morphology of $\mathrm{CaTiO}_{3}$ films changed from dense fine grain to cauliflowerlike columnar texture with increasing $P_{\mathrm{O}_{2}}$ and $T_{\text {sub. The }}$ $\mathrm{CaTiO}_{3}$ films containing $\mathrm{Ca}_{2} \mathrm{Ti}_{2} \mathrm{O}_{6}$ were obtained at $T_{\text {sub }}=$ $1073 \mathrm{~K}, R_{\mathrm{Ca} / \mathrm{Ti}}=0.72$ to $0.59, P_{\text {tot }}=0.8 \mathrm{kPa}$ and $P_{\mathrm{O}_{2}}=$ $0.32 \mathrm{kPa}$. These films had edged angular grains and significant (010) orientation. The activation energy for the deposition was about $70 \mathrm{~kJ} \mathrm{~mol}^{-1}$ suggesting a chemical reaction limited process. The highest deposition rate of $\mathrm{CaTiO}_{3}$ film in a single phase was $1.25 \times 10^{-8} \mathrm{~m} \mathrm{~s}^{-1}$ at $T_{\text {sub }}=1073 \mathrm{~K}, \quad P_{\text {tot }}=0.4 \mathrm{kPa}$ and $P_{\mathrm{O}_{2}}=0.32 \mathrm{kPa}$. The deposition rate of films increased with increasing $P_{\mathrm{O}_{2}}$ and $T_{\text {sub }}$, and decreasing $P_{\text {tot }}$.

\section{REFERENCES}

1) A. Yamamoto, R. Honma and M. Sumita: J. Biomed. Mater. Res. 39 (1998) 331-340.

2) M. Papakyriacou, H. Mayer, C. Pypen, H. Plenk, Jr. and S. StanzTschegg: Int. J. Fatigue 22 (2000) 873-886.

3) C. X. Wang, Z. Q. Chen, L. M. Guan, M. Wang, Z. Y. Liu and P. L. Wang: Nucl. Instr. Meth. Phys. Res. Sec. B: Beam Interactions with Materials and Atoms 179 (2001) 364-372.

4) J. L. Arias, M. B. Mayor, J. Pou, Y. Leng, B. Leon and M. Perez-Amor: Biomaterials 24 (2003) 3403-3408.

5) G. Bikulius, V. Burokas, A. Martuien and E. Matulionis: Surf. Coat. Tech. 172 (2003) 139-143.

6) M. Hsieh, L. Perng and T. Chin: Mater. Chem. Phys. 74 (2002) 245250.

7) M. Manso-Silván, M. Langlet, C. Jiménez, M. Fernández and J. M. Martínez-Duart: J. Europ. Ceram. Soc. 23 (2003) 243-246.

8) A. Stoch, A. Broek, G. Kmita, J. Stoch, W. Jastrzbski and A. Rakowska: J. Mol. Struct. 596 (2001) 191-200.

9) L.-G. Yu, K. A. Khor, H. Li and P. Cheang: Biomaterials 24 (2003) 2695-2705.

10) L. In-Seop, K. Dong-Hwan, K. Hyoun-Ee, J. Young-Chul and H. Chong-Hyun: Biomaterials 23 (2002) 609-615.

11) C. H. Han, C. B. Johanson, A. Wennerberg and T. Albrektsson: Clin. Oral. Impt. Res. 9 (1998) 1-10.

12) A. Montenero, G. Gnappi, F. Ferrari and M. cesari: J. Mater. Sci. 35 (2000) 2791-2797.

13) Y. Fujishiro, N. Sato, S. Uchida and T. Sato: J. Mater. Sci.: Mater. Med. 9 (1998) 363-367.

14) R. Tu and T. Goto: Mater. Sci. Forum 475-479 (2005) 1219-1222.

15) T. Kimura and T. Goto: Mater. Trans. 44 (2003) 421-424.

16) T. M. Besmann: Oak Ridge National Laboratory Tech. Report No. ORNL/TM-5775, (1977).

17) JANAF Thermochemical Tables, American Chemical Society and American, (Institute of Physics for National Bureau of Standards, 1985).

18) I. Barin: Thermochemical Data of Pure Substances, (VCH, Weinheim, 1989).

19) C. J. Ball, R. G. Blake, D. J. Cassidy and J. L. Woolfrey: J. Nucl. Mater. 151 (1988) 151-161; through JCPDS Card No. 42-0423.

20) M. M. Elcombe, E. H. Kisi, K. D. Hawkins, T. J. White, P. Goodman and S. Matheson: Acta Crystallogr. Sec. B 47 (1991) 305-314; through JCPDS Card No. 78-2481.

21) C. E. Morosanu: Thin Films by Chemical Vapor Deposition, (ELSEVIER, 1990) p. 101.

22) R. Tu and T. Goto: Mater. Trans. 46 (2005) 1318-1323. 